https://doi.org/10.18485/cosic_dobrica.2018.ch22

811.163.41'38

821.163.41.08-31ћосић Д.

\author{
ТОМИСЛАВ М. МАТИЋ* \\ Универзитет у Београду \\ Филолошки факултет
}

\title{
ПОРЕДБЕНЕ КОНСТРУКЦИЈЕ ИДИОМАТСКОГ КАРАКТЕРА У КОРЕНИМА Д. ЋОСИЋА
}

\begin{abstract}
У раду ће бити приказане и анализиране поредбене конструкције ексцерпиране из романа „Корени” Добрице Ћосића. Структурна и семантичка класификација и анализа овог маркираног сегмента језичког система омогућиће нам увид у сам чин стварања карактеристичног пишчевог песничког израза. Покушаћемо да утврдимо степен идиоматизованости поредбених конструкција, њихов међусобни однос, као и лексичке и синтаксичке специфичности њихове реализације у роману.
\end{abstract}

Кључне речи: Добрица Ћосић, поређење, поредбена реч, поређена реч, идиоматизација, класификација, анализа.

\section{1. Увод}

1.1. У терминолошким речницима поређење или компарација дефинише се нпр. као „изражајно средство којим се неко својство, стање. дјеловање и сл. објашњава, чини ближим, стилистички истиче и афективно појачава довођењем у везу с познатијим својством итд." (РКТ s. v.). Радоје Симић (2000: 265-266) скреће пажњу на основни поступак компарирања као на индиректно изношење неке особине или сл.: „Особине једнога чињеничног елемента не описују се директном номинацијом, већ 'преношењем' пажње на неки други опис, уз чију се помоћ први чињенични склоп 'приказује'. Приближавање двају појмова, не тако чврсто као у метафори, не укида њихову двојност".

1.2. Зденко Лешић у својој књизи о језику књижевног дела (Лешић 1982: 299-300) поређењу и метафори придаје значај основних и најзначајнијих средстава „у формирању 'поетских' значења”:

*t.matic@yahoo.com 
Многи су у њима видјели основне инструменте пјесничке имагинације, а још за Аристотела они су били „знак генија”: „јер начинити успјелу метафору значи уочити сличност". А управо то откривање сличности међу стварима у основи је пјесникове умјетности, како сами пјесници тврде. Од свих људских способности „само поезија може да схвати универзалну аналогију (l'analogie universelle)” - казао је Бодлер. А Вордсворт је „највећи извор наших духовних активности” видио у „задовољству што га дух има кад открива сличности у разликама".

1.3. Милош Ковачевић у својој познатој књизи о стилским фигурама (Ковачевић 1995: 58) не расправља посебно о поређењу, а највероватнији разлог томе је управо свепрожимност поетског текста осећањем аналогије, како рече Лешић цитирајући чувене песнике и теоретичаре. И заиста, он на више места своје књиге помиње поређење као компоненту фигуративног израза виших, одн. сложенијих структурних типова. Говорећи о градацији, и 'поредбеним корелатима у њеном оквиру' - утврђује:

Док количински начински модели указују на количинску подударност и семантичку једнаковриједност поредбених корелата с односом колико-йолико, градациони модел пермутира замјеничке прилоге успо-

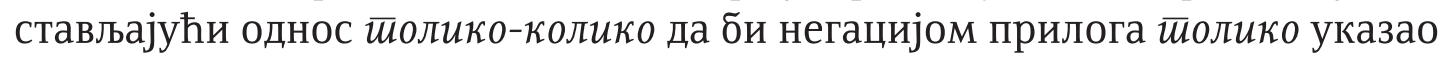
на неједнаковриједнст квантификованих садржаја. Негацијом квантификатора йолико отвара се мјесто за навођење постцедентног поредбеног корелата, али се тиме и предодрећује већи значај садржају израженом поредбеним корелатом.

1.4. О идиомима и идиоматици. Р. Симић у већ навођеној књизи (Симић 2001: 282-289) износи мишљење да се идиомом може сматрати „свака реч или било која друга језичка јединица као носилац специфичног односа датога језичког колектива према реалним околностима у којима живи, према сопственој култури и традицији, у којима се та реалност прелама". Тиме језички знак добија специфична својства и статус издвојеног елемента језичког комплекса којим се служи дати колектив. Такав статус омогућава му да на најефикаснији начин „означи претставу" (по речима А. Белића, 1998: 43-44). Дефинишући идиоматику у Рјеинику линівисиичиких назива као „укупност идиома којега језика", 1 Р. Симеон истиче да „у идиоматику улазе пословице, узречице, пошалице, устаљене изреке. Идиоматика опћег (националног) језика обогаћује се најчешће из специјалних језика; извори су јој најчешће у фолклору, у црквеном и библијском језику, у арготу и књижевности итд." (Симеон

${ }^{1}$ Ово је у ствари основна дефиниција, под бројем 1; друге две дефиниције везују идиоматику за фразеологију, као њен део или пак као њен синоним. 
1969: 507). Управо грађа ексцерпирана из Ћосићевог романа на двосмеран начин потврђује дефинисане процесе идиоматизације: стварајући свој аутентични песнички израз, Ћосић управо на бази идиоматских израза карактеристичних за наш језик, ствара оригиналне изразе највишег уметничког ранга готово дословно црпећи грађу из локалног (моравског) фолклорног дискурса.

1.5. Даље, поставља се питање зашто постоји потреба употребе идиоматских јединица у поређењу, и каква је њихова функција у тој конструкцији. Чини се да је најближе одговору на то питање оно што у својим анализама пословичких поређења утврђује Ј. Јовановић Симић (2006, 2007): да се нпр. сликовита представа јавља по правилу у поредбеном делу конструкције и да има посебну, пре свега појачајну функцију (Јовановић 2007: 167-168):

Уношењем сликовитих детаља у поредбени део конструкције поређење је добило сасвим нове димензије, продубљено је и осветљено јасном светлошћу умешног казивања [...] Народни стваралац оживљава сећање на детаље из сопствене околине и искуства у њој стечена, а визуелизује их употребом живих, семантички јаких речи. На тај начин обезбеђује изреци свежину и упечатљивост.

Управо то потврђују и готово сви примери из нашег корпуса. Ћосић доследно користи поредбени део конструкције како би у свој романескни дискурс увео специфичну лексику (и фразеологију) Србије између Морава, а са њом и све имплицитне метафоре и нијансе значења, језичку слику света тога ареала.

\section{2. Преглед грађе}

2.1. По ономе што је речено у уводним напоменама већ можемо очекивати како ће се понашати идиоматизоване јединице у оквиру поређења која налазимо код Добрице Ћосића. Ипак, пре но што пређемо на анализу грађе, ваља рећи да смо поредбене конструкције у Коренима сразмерно врло често бележили, рекло би се да су чешће него све остале фигуре заједно. ${ }^{2}$ Ексцерпирана грађа доноси нам богат регистар како уобичајених неидиоматизованих поређења, тако и идиоматизованих, те и оних најуспелијих, уметничких поређења насталих на бази идиомат-

2 Још Светозар Георгијевић (1955: 181), у једном од првих приказа и анализа Корена, каже „да је Ћосићева реченица кратка, поетска, пуна фигура - метафора и поређења. Једна емоционална реченица, монолошка, реченица човека који говори сам са собом." Већина ексцерпираних примера у нашем раду, по правилу најефектнијих, управо и јесте из таквих - монолошких реченица. 
ских поредбених конструкција. Ова околност то значајно Ћосићево дело ставља у ред књижевних остварења врло блиских народној речи, и по духу и по оваквим конкретним језичким својствима.

2.2. Још једна напомена мора претходити анализи. Идиоматизација језичких елемената јесте фазни процес, па се у језику они налазе на скали од израза потпуно у складу са језичким обичајима, неидиоматизованих израза, преко оних који су у почетној фази идиоматизације па до израза у касној фази идиоматизације и, на крају, оних језичких елемената, израза код којих је идиоматизација потпуна - завршена. Тако се и поредбене конструкције могу рангирати по томе у којој би се фази идиоматизације нашао језички материјал од којега су сачињене. Покушаћемо да установимо какав је однос, и квантитативни и квалитативни, међу изразима на овој специфичној скали.

\section{3. Класификација и анализа грађе}

3.1. Класификацију ексцерпиране грађе извршићемо према врсти поређене речи. Најређе бележени примери су са именицом у позицији поређене речи, док су примери са глаголом у тој позицији најбројнији. У раду ћемо анализирати примере са именицама, глаголима и придевима у позицији поређене речи.

3.1.1. Конструкције са именицом као поређеним елементом су, како смо рекли, најређе - забележили смо свега три примера. Међутим, то ни у ком случају не умањује њихову поетску вредност, а ни значај за наш рад, будући да и та три примера потврђују разнородност на скали идиоматизацијских процеса, представљену у форми хипотезе у уводном делу рада.

О коме се у Прерову прича да има иессницу као маљ

По тим њивама као йканища ору мршаве кравице. $\mathrm{Ja}[\ldots]$ сиромах ко сирће.

а) Поређена реч у првом од три наведена примера јесте 'песница', а поредбена 'маљ'. Управо 'маљ' даје поређењу упечатљивост јаког израза. 'Маљ' се у РМС дефинише као 'повелико гвоздено, железно или дрвено оруђе у облику чекића којим се млати, туче, кује, разбија, забија или набија'. У народском језику такво поређење није ретко, те је маљ постао нешто као симбол снаге, али и тврдоће. ${ }^{3}$

б) У РМС се 'тканици' приписује као примарно значење 'откан појас (у разним бојама и шарама)', док је секундарно, са квалификато-

${ }^{3}$ Насупрот поређења песнице, када се пореди глава са маљем, резултат је донекле пејорацијска деградација: у позадини је квалификатив 'глупа'. 
ром йокр. 'узак пут, стаза'. Њива поређена са тканицом у другом значењу интензивно је окарактерисана као сиромашка, као симбол беде. Покушава се дочарати контраст између газдинских великих поседа и ситних, распарчаних њива које су од њих откупљивали сиромашни људи, слуге, надничари. Треба нагласити и синтаксичко одступање у овом поређењу - 'тканица' је у облику номинатива једнине уместо очекиваног локатива множине. Ипак, ако претпоставимо да је из поредбене конструкције елидирано 'које изгледају', она постаје синтаксички коректна и прихватљива. Тада би се разјашњење овог ефектног поређења могло потражити и у примарном значењу лексеме у РMC - будући да аутор све те њиве (њивице) узима као једну слику, она заиста може заличити на 'појас у разним бојама и шарама'.

в) 'Сиромах ко сирће' мало је изненађујући обрт, али смисао му је јасан, јер сирће и лук били су најчешћи оброк сиромашних сеоских породица, чак и у доба најтежих летњих радова на њиви. Структурном елипсом коју прати метафоричко (метонимијско) преношење од ширег 'сиромах као особа (човек) која једе (само) лук и сирће' дошло се до цитираног израза.

Све у свему, нема двојбе да поређена реч у нашим конструкцијама има у сваком погледу подређен комуникативни статус, а да поредбена реч доминира, и уз то је резултат посебног избора, било по упечатљивости, било по необичности значења или употребе. Све су то симптоми почетног процеса издвајања тих речи из окружења и слабије или јаче узнапредовалог идиоматизовања, како је схваћено у тумачењима Р. Симића.

3.1.2. Конструкције са глаголом у позицији поређене речи далеко су бројније, следствено томе су и структурно и лексемски, фразеолошки разноврсније - Ћосићев поетски израз се у њима и кроз њих остварује у свој пуноћи уметничке форме изграђене на бази народске речи. ${ }^{4}$

Живим ирюе оg манастиирскої йса!

Узеће себи момка и живеће као кнеїиюа.

Не знаш ти шта су они (дукати). Могу да иеевају као йиице. Да ииче као крgо йрасића. Да се смеју као йрещња иууна gеще. Од њих је кућа већа оg неба.

Tu üричащ као ga шамаращ љуgе. Наш народ воли тешку и спору реч.

Док сам се ја по ваздугу ноћ иреврииала као ирв на жеравици.

Узимала сам те у наручје и иеела на себе, као шйо се gейе иеюње на коња.

Као свој кожух иоознајем ову Србијииу.

${ }^{4}$ В. О локалној и сличној лексици у Ћосићевим 'Коренима' (Јовановић 2009). 


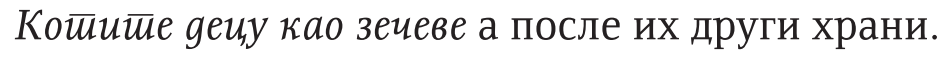

Кеса с gукайима жуљи ребра, као gа је белуйак.

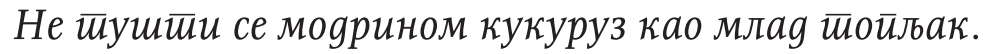

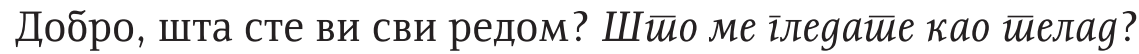

Ико, дај им ракије, док не поцркају! Видиш ли да чуче око мене као куиићи?

[...] она (стрина Вишња) је већ седела и gисала истио онако йласно као крава.

Знам йе као кошуљу.

Деди Луки лакше је било. Живео сам као воgничарско йсейо.

[...] па жив није да Вукашина не сретне, да га не види како се као бостианско йсейо шуюа око њет̄ове іосйоgске куће, у заранке.

А син, не син, већ синови, рађаће их она као зечии, .

Узбуђенија, убрзала је корак, још више одмичући од мајке, која се за њом као снои мрака заgихано суљала.

Бацила се на кревет с тихом песмом малог звона у ушима, узела Ђорђа у наруије, лако, као сной ражи.

[...] с мржњом и нежношћу што су се у налетима смењивале као велико и мало звоно, [...].

Морава као челей омииа рже на спрудовима.

а) Прву напомену заслужују примери устаљених инспиративних

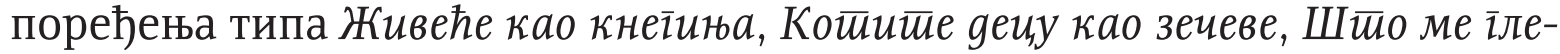

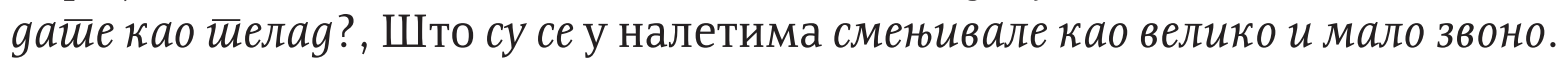
- Код њих је, може се рећи, идиоматизација завршена, или је затечена у врло поодмаклој фази.

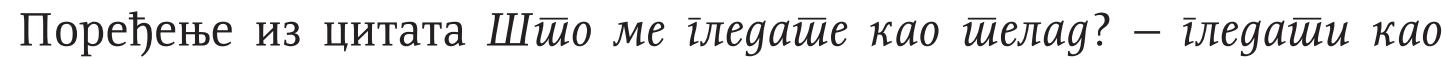
चеле, лексикализовано је у структурно-семантички проширеној форми у Речнику MC (PMC VI: 172):

као у шарена (нова) врата (бленути, буљити, гледати), као пред шареним

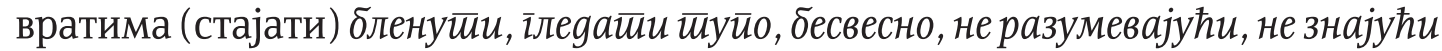

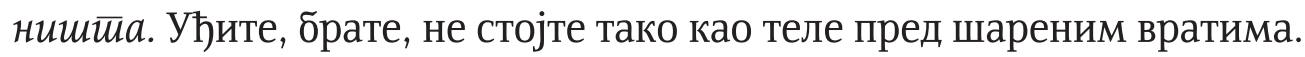

Ово је, дакле, експлицитни доказ да је процес идиоматизације овог израза завршен и да, као такав, постоји у фразеолошком корпусу српског књижевног језика. Израз је проширен, или вероватније, у Ћосићевом примеру елидирана је допуна у шарена врай $а$, чија је суштинска функција заправо интензификација пејорацијске (негативне) семантичке компоненте из дефиниције израза. У нашем примеру и структурну и семантичку улогу поредбеног дела конструкције преузима само именска

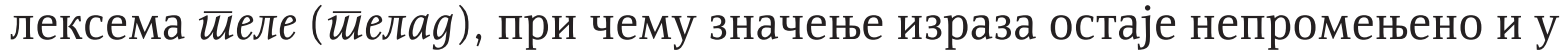
потпуности одговара дефиницији из речника. 
б) Супротна су овима поређења свакодневног говора, која остају на нивоу обичног израза, и не одударају ни посебним структурним осо-

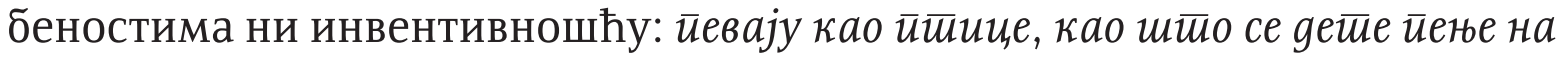
коња, чуче око мене као кучићи, gисала исиоо онако иласно као крава, узела Ђорђа у наручје, лако, као сной ражи. Може се евентуално дискутовати о њиховој обележености на временској или дијалекатској (дијахронијској или дијатопијској) оси, и о томе да ли они како такви улазе у фонд српског књижевног израза. Међутим, како смо нагласили на почетку рада, Ћосићева намера је и била да изразито иновативним и инвентивним приповедачким поступком, којег прати специфична (и обележена) лексика и фразеологија, (о)слика Србијицу, Србију између Морава, стару Србију с краја XIX века.

в) Овећа је група конструкција са инвентивно одабраном поредбеном лексемом, али су то по свој прилици индивидуалне креације самог писца: Живим ирње оg манасииирскої йса! Да се смеју као йрешња йуна gеце, Ти иричаш као gа шамараш љуяе, која се за њом као сной мрака заgихано суљала.

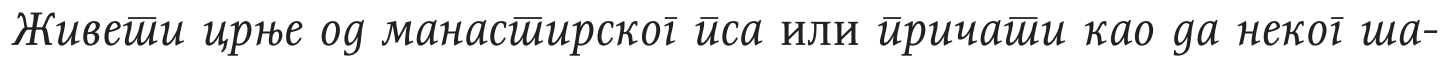
марамо - спадају у експресивне изразе не највишег ранга естетске вредности. Поређење човекова живота са животом пса веома је честа појава и може се рећи да је и у синтагми 'пасји живот', а и у самом поређењу 'живети као пас' процес идиоматизације завршен, те да су ти изрази ушли у фразеолошки корпус нашег језика. ${ }^{5}$ Из ексцерпиране грађе видимо да Ћосић у још два случаја експресивност (и нијансност) поређења постиже сличним структурно-семантичким ширењем поредбеног дела

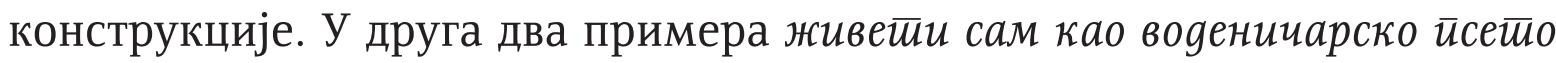

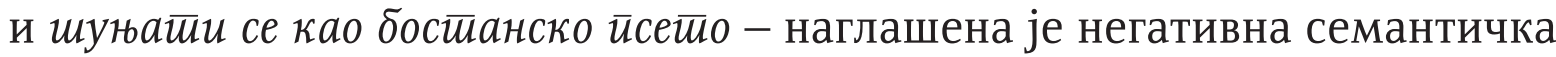
компонента лексеме 'пас' употребом пејорацијског 'псето'.

С друге стране, обрти gа се смеју као йрешња йуна gеще, те која се као сной мрака заgихано суљала - морају се рангирати у врх уметнички изграђених форми.

((Дукати) могу) gа се смеју као йрешња йуна gеще - смејайи се као иирешња йна gеu,

У Асоцијатиивном речнику срйскоїа језика се као прва асоцијација на придев 'дечји' наводи 'осмех' (142), док је на другом месту 'смех' (84) (Пипер, Драгићевић и Стефановић 2005: 173). Видимо, дакле, да на семантичко-асоцијативном плану цитирано поређење представља когнитивну релацију карактеристичну за наш језик и мишљење. Ипак,

${ }^{5}$ Živjeti ipf. kao pas - bijedno / loše živjeti (pod teškim materijalnim prilikama) (Матешић 1982: 454). 
оригиналност и ефектност поређења постигнута је ширењем поредбеног дела поређења. Да бисмо их боље разумели, неопходно је сагледати низ поредбених конструкција чији је саставни део цитирано поређење: Не

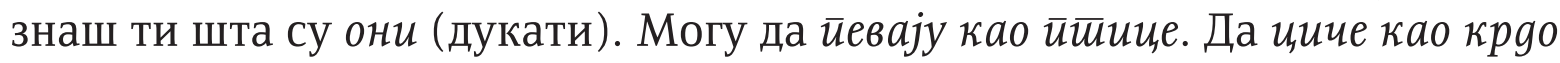
йрасића. Да се смеју као йрешња йуна gеще. Од њих је кућа већа оg неба. Ово су Ђорђеве речи којима Толи објашњава своју опчињеност дукатима - тачније звуком дуката када их је пуна кеса. Сема звука је доминантна у прва три поређења, док четврто ни структурно ни семантички не припада истом низу (типу). Приказујући ове „звучне слике” Ћосић даје суштинске концепте (руралне) идиле Србије тога (можда и данашњег) времена: пој птица као метафора очуване и здраве животне средине, цичање прасади (прасића) као симбол имућности, очување и ширења богатства, дечји смех као слика апсолутне среће и немерљиве радости коју суживот човека и природе пружа. Даље би се дало расправљати о евентуалној градацијској увезаности ова три поређења, нарочито ако се узме у обзир контекст разговора Ђорђа и Толе, али и Ћосићева централна идеја о 'окорењености' и 'укорењености' као априорном богатству и животној осмишљености.

Узбуђенија, убрзала је корак, још више одмичући од мајке, која се за њом као сной мрака заяихано суљала - суљайи се као сной мрака.

У Речнику Матице српске (РМС 1967-1976) приказано је читаво лексемско језгро глагола 'суљати (се)', па тако имамо видски пар 'суљати (се)' и 'суљнути (се)', као и итеративни облик 'суљкати (се)', уз који стоји и (квалификатор) gем. према 'суљати (се)'. Облици придева и глаголске именице, настали на истој основи, 'суљави' 'суљање', употпуњују лексемску парадигму и потврђују чињеницу да лексема припада фонду српског књижевног језика. Ипак, у језичком осећању савремених говорника српскога језика ова се лексема најчешће посматра обележеном, било као застарела реч, било као локализам (дијалектизам). Тако да се супротстављањем овога примера осталим (разнотипним) поређењима из ексцерпиране грађе, види да се он издваја избором поређене речи (глагол, у овом случају), која није у апсолутно подређеном (комуникативно-стилематичном) положају у односу на поредбени део конструкције, што је случај са великом већином забележених примера, без обзира на врсту поређене речи. Експресивност поређене речи у овом примеру ни у ком случају не умањује уметничку изузетност обрта које поредбени део конструкције, заправо поређење у целини доноси.

На крају ћемо навести и анализирати јако ефектно поређење које припада немалој групи примера који се структурно разликују од поређења цитираних на почетку овога одељка - примери поредбених конструкција које су, у мањој или већој мери, кондензоване, најчешће с циљем појачавања експресивности исказа. 
Два војника јурнуше на жену, она стаде, чвор на лицу јој се смањи,

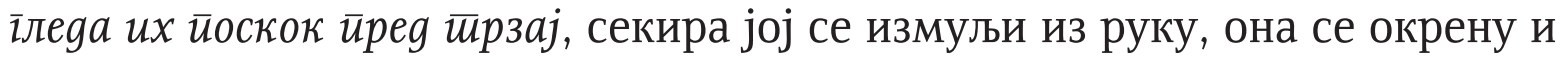
полако пође низ пут за коњима - іллеgатии (некоїа) као йоскок йреg йрзај.

Наводимо нешто шири контекст како би приповедачки поступак а с њим и само поређење били сагледивији и јаснији. Оно се синтаксички издваја изостављањем поредбеног везника (везничке конструкције). Схема поређења остаје иста - поређена реч је немаркирана, док се поредбени део конструкције издваја експресивношћу, односно инвентивним одабиром лексема (фразема), као инхерентним делом мозаика Ћосићеве слике света (Србије). Најчешћа реализација оваквих кондензованих поређења у роману је низање разбијених синтаксичких форми, ${ }^{6}$ чиме се, уз елидирање везника, додатно доприноси динамичности радње. У овом примеру се управо структурним континуитетом наглашава гротескност и неочекиваност ситуације, појачавају све супростављености које чине ову сцену и оно што јој непосредно претходи, а нарочито истиче њен кататонични завршетак.

3.1.3. Конструкције са придевом у позицији поређене речи честе су у Ћосићеву исказу, структурно, лексемски и фразеолошки сличних су карактеристика као и претходно анализиране конструкције са глаголом као поређеном речи.

Поред њега, у њен поткорућен лежај брзо се увуче сйуg, језива као оgран иовек, и он виде Мијайа како се, мршав и gуїаиак као кер, протеже у његовој постељи.

Од Ђорђа Катића немаш шта да узмеш. Јалов је као ирни јасен.

Не плачи, несанко моја. Сутра, на празник, биће тии очи као ољушиеене шљиве.

И можеш сад да спаваш, тако си ружан и мали као іища. Хрчеш [...].

Једино срие круйније оg gулека и лавеж за петама могу по првом леду да споје две обале.

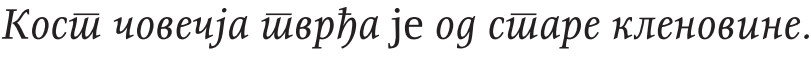

туйње у бубним ойнама, нараслим, великим као наgувене іајgе.

Да је другачија од његове Живане, йанке, мале и савијене као махуна йасуљь у сушној їолини.

Ништа ми ниси донела, gошла си іола као леска, кошуљу ниси имала.

[...] да се не би срушиле на грудве, суве и круйне као іробљанско камење.

Себииан си као іллаgан курјак.

${ }^{6}$ Ал мој отац је био воденичар и слуга. Лисииић на коловозу. Лука дошљак; Враћам се опет ноћу, тако и зверке чине; ја, јазаваu, с браgом, у подрум на лежај; А ти знаш каква је твоја душа: рибица у крви! Не можеш да умреш с њом; У чуђењу му се отворише уста

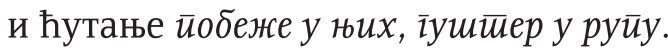


Памтиш ли колико пута си пред туђинцима рекао да ми је нарав йолико лоша као gа су ме Турии ирравили.

Јуйро је сиво, као и мозак без чеоне косии, ни ледена кора снега што је оковала кровове и земљу није хладнија од његове коже.

[...] штала је ииоила као жена, и кисела као она, [...].

У собу улете брза звоњава црквеног звона. Одјекује у њој исиражненој $u$ великој као манасӣир.

[...] двапут је на манастирској слави видела ту чађаву руку и била је ружнuја og козјеі зайоњка.

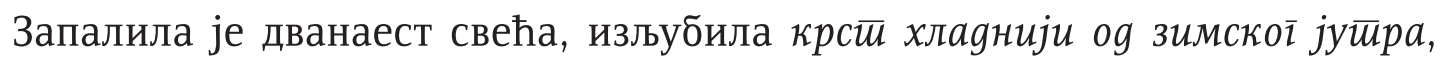
ставила дукат [...].

Планинским усеком провањало се маїареће њакање їаgно као луgачки смех, губећи се у звоњави за јутрење.

а) Очекивани резултат поменуте структурне и лексемске сличности свакако јесте и могућност сличне класификације најуспелијих поредбених конструкција. Тако ћемо у прву групу сврстати примере устаљених израза код којих је процес идиоматизације завршен. Такви би били изрази Себичан си као йлаgан курјак, [...] gа ми је нарав йолико лоша као gа су ме Тури, ир авили или Ништа ми ниси донела, gошла си іола као леска, кошуљу ниси имала.

б) Другу групу примера чинила би поређења из свакодневног говора, прозирна и јасно мотивисана. Таква су поређења Туйње у бубним ойнама, нараслим, великим као наgувене іајge или [...] да је другачија од његове Живане, йанке, мале и савијене као махуна йасуља у сушној їолини. У извесну подгрупу овим примерима могли бисмо сврстати поређења чије значење није потпуно јасно (с аспекта данашњег језичког узуса) - поређења са недовољно прозирном мотивацијом, Од Ђорђа Катића немаш шта да узмеш. Јалов је као ирни јасен, и примере са дијалекатски изразито маркираном поредбеном лексемом, И можеш сад да спаваш, тако си ружан и мали као іича или Једино срие круйније og gулека и лавеж за петама могу по првом леду да споје две обале.

в) Баш као и код претходно анализираних примера са глаголом на месту поређене речи, забележен је немали број конструкција са инвентивно одабраном поредбеном лексемом, а за које смо рекли да представљају аутохтоне Ћосићеве уметничке творевине: Поред њега, у њен поткорућен лежај брзо се увуче сйyg, језива као оgран човек, Планинским усеком провањало се маїареће юакане іаgно као луgачки смех или Јуйро је сиво, као и мозак без чеоне косиич. И овде би се могло расправљати о њиховој уметничкој вредности и мери у којој она излазе из оквира језичког стандарда, али се свако може констатовати да управо овакве 
конструкције, уз оригинални приповедачки поступак, чине есенцију ауторовог поетског израза у Коренима.

3.1.4. На самом крају нашег рада, а пре закључка, наводимо једну од успелијих реченица из романа, која се састоји из два разнотипна поређења. Првог, структурно оивиченог, схематизованог модела анализираног у раду, са инвентивно одабраном поредбеном лексемом, и другог, уметнички највише рангираног, и безмало рефренског представника укупног Ћосићевог поетског исказа у Коренима.

Никаg сељаико gейе није йако безобразно као ова иосйоgска найужа, мис-

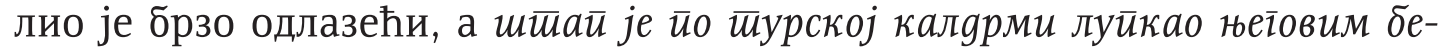
жањем, йусйо, заболело, као gа йо юеїовој осушеној ілави неко йуче изяужену слабости шйо не може gа се не йонижава.

\section{4. Закључак}

4.1 Ћосићева поређења чине скалу разнородних и разнотипних формација које између осталог врло високо подижу тон његовог приповедачког умећа. Истовремено, лексика и фразеологија његових поређења - такође чине скалу што се тиче идиоматизацијских процеса којима су захваћене. Опет, неидиоматизоване ауторске конструкције са инвентивно одабраном поредбеном речи, веома често позиционираном у срж лексичко-семантичке и дијалекатске равни Николине, односно Ћосићеве Србијице, комбиноване са иновативношћу самог приповедачког поступка, чине песнички израз Корена, а и сам роман, једном од најлепших уметничких креација српског језика.

\section{ИЗВОРИ И ЛИТЕРАТУРА}

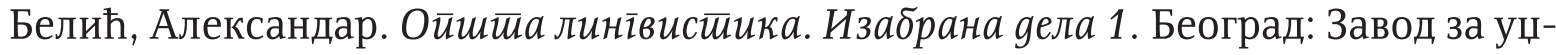
бенике, 1998. Шт.

Георгијевић, Светозар. „Белешке о језику и стилу у Коренима Д. Ћосића”. Наш језик, књ. VI, св. 5-6 (1955): 179-186. Шт.

Живковић, Драгиша (ур.). Речник книжевних иеермина. Београд: Нолит, 1992. Шт.

Илијашевић, Воја. „Два аспекта и два стила Ћосићевих романа”. Кюижевности и језик, IV, св. 9 (1957): 320-333. Шт.

Јовановић, Јелена. „Поредбене пословичке форме - конструкције са речцом као". Срйски језик, ХI (2006): 115-165. Шт.

Јовановић, Јелена. „О локалној и сличној лексици у Ћосићевим Коренима”. Науини састианак слависйа у Вукове gане, 38/1 (2009): 163-176. Шт.

Јовановић, Јелена. „О синтаксичким и стилским особеностима изградње сликовите представе". Срйски језик, XII (2007): 141-169. Шт. 


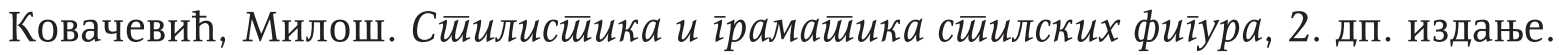
Никшић: Унирекс, 1995. Шт.

Лалевић, Миодраг. „Белешке о језику и стилу у Коренима Д. Ћосића”. Haw jeзик, књ. VI, св. 5-6 (1955): 169-179. Шт.

Matešić, Josip. Frazeološki rječnik hrvatskoga ili srpskoga jezika. Zagreb: Školska knjiga, 1982. Шт.

Пипер, Предраг, Рајна Драгићевић и Марија Стефановић. Асоиијатиивни реиник срйскоїа језика. Београд: Београдска књига, Службени лист СЦГ, Филолошки факултет, 2005. Шт.

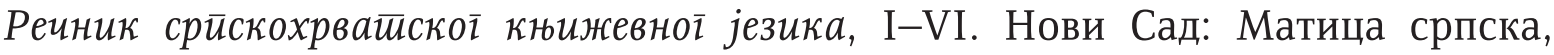
1967-1976. Шт.

Речник срйскоїа језика. Нови Сад: Матица српска, 2007. Шт.

Simeon, Rihard. Enciklopedijski rječnik lingvističkih naziva (A-O). Zagreb: Matica hrvatska, 1969. Шт.

Simeon, Rihard. Enciklopedijski rječnik lingvističkih naziva (P-Ž). Zagreb: Matica hrvatska, 1969. Шт.

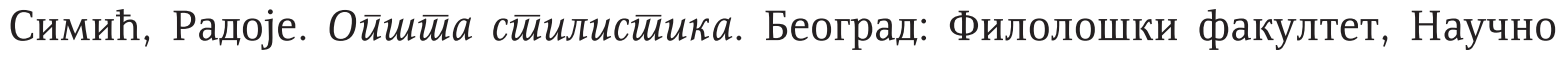
друштво за неговање и проучавање српског језика, 2001. Шт.

Ћосић, Добрица. Корени, 12. издање. Београд: Просвета, 1973. Шт.

Tomislav M. Matić

COMPARATIVE CONSTRUCTIONS OF IDIOMATIC CHARACTER IN

D. ĆOSIĆ'S ROOTS

\section{Summary}

The paper presents and analyses comparative structures excerpted from Dobrica Ćosićs novel Roots. The structural and semantic classification and analysis of this marked segment of the linguistic system has facilitated fundamental insights into the very act of creation of the author's typical poetic expression. We have established the existence of idiomatised comparative constructions, their mutual interrelations, as well as the lexical and syntactic specificities of their realisation in the novel. 